\title{
A New Model for Predicting Energy Requirements of Children during Catch-Up Growth Developed Using Doubly Labeled Water
}

\author{
CARLA R. FJELD, ${ }^{1}$ DALE A. SCHOELLER, AND KENNETH H. BROWN \\ Instituto de Investigación Nutricional, Lima, Perú [C.R.F.], Department of Medicine, The University of Chicago, \\ Chicago, Illinois 60637 [C.R.F., D.A.S.], and Division of Human Nutrition, The Johns Hopkins University, \\ Baltimore, Maryland 21205 [K.H.B.]
}

\begin{abstract}
Energy partitioned to maintenance plus activity, tissue synthesis, and storage was measured in $\mathbf{4 1}$ children in early recovery $[\mathrm{W} / \mathrm{L}(\mathrm{wt} /$ length $)<5$ th percentile] from severe protein-energy malnutrition and in late recovery $(\mathrm{W} / \mathrm{L}=25$ th percentile $)$ to determine energy requirements during catch-up growth. Metabolizable energy intake was measured by bomb calorimetry and metabolic collections. Energy expended $(\bar{x} \pm$ SD) for maintenance and activity estimated by the doubly labeled water method was $97 \pm 12 \mathrm{kcal} / \mathrm{kg}$ FFM (fat-free mass) in early recovery and $98 \pm 12 \mathrm{kcal} / \mathrm{kg}$ FFM in late recovery $(p>$ $0.5)$. Energy stored was $5-6 \mathrm{kcal} / \mathrm{g}$ of wt gain. Tissue synthesis increased energy expenditure by $1 \pm 0.7 \mathrm{kcal} / \mathrm{g}$ gain in both early and late recovery. From these data a mathematical model was developed to predict energy requirements for children during catch-up growth as a function of initial body composition and rate and composition of wt gain. The model for predicting metabolizable energy requirements is $[(98 \times \mathrm{FFM}+\mathrm{A}(11.1 \mathrm{~B}+2.2 \mathrm{C})]$, kcal/ $\mathrm{kg.d}$, where FFM is fat-free mass expressed as a percentage of body wt, A is wt gain $(\mathrm{g} / \mathrm{kg} \cdot \mathrm{d}), \mathrm{B}$ and $\mathrm{C}$ are percentage of wt gain/100 as fat and FFM, respectively. The model was tested retrospectively in separate studies of malnourished children. (Pediatr Res 25:503-508, 1989)
\end{abstract}

\section{Abbreviations}

APE, atom percent excess

$\mathrm{rCO}_{2}, \mathrm{CO}_{2}$ production rate

$\mathbf{E E}_{\mathrm{m}+\mathrm{a}}$, energy expenditure for maintenance and activity

ES, energy stored

FFM, fat-free mass

ME, metabolizable energy

PEM, protein-energy malnutrition

SMOW, Vienna Standard Mean Ocean Water

TBW, total body water

TDEE, total daily energy expenditure

W/L, wt-for-length

Current nutritional guidelines for energy requirements of children are based on observations of energy intake (1). It has been

Received August 29, 1988; accepted December 27, 1988.

Correspondence and reprint requests D. A. Schoeller, University of Chicago, Department of Medicine, Box 223, 5841 S. Maryland Ave., Chicago, IL 60637.

Supported by The Thrasher Research Fund (D.A.S.) and NIH Grant DK 30031 (D.A.S.).

Current address Metabolism Division, Box 8127, Washington University School of Medicine, $660 \mathrm{~S}$. Euclid Ave., St. Louis, MO 63110. recommended, however, that new evaluations based on energy expenditure be made when methods and data become available (1). This need is particularly acute for malnourished children who enter into a period of rapid growth during treatment.

Recently, the doubly labeled water method for measuring longterm daily energy expenditure was validated in preterm infants (2) and postsurgical infants (3). This method does not interfere with normal clinical treatment and thus provides the necessary component for new evaluations of energy requirements during recovery from malnutrition.

During recovery from malnutrition, the required intake of matabolizable energy is partitioned between energy expenditure for maintenance and activity $(m+a)$, energy expenditure for new tissue synthesis, and energy stored in new tissues. Because energy expenditure for $\mathrm{m}+\mathrm{a}$ is partially dependent on fat-free mass (4) and because energy stored is dependent on the composition of the new tissue, concurrent measures of body composition would further facilitate the reevaluation of energy requirements. We therefore applied the doubly labeled water method to develop a model for predicting metabolizable energy requirements of children with growth failure secondary to proteinenergy malnutrition.

\section{METHODS}

Subjects. Children studied (Table 1) were from periurban areas of Lima, Perú, and were being treated for PEM in an in-patient metabolic ward. They were classified as being either in early recovery $(\mathrm{W} / \mathrm{L}<5$ th $\mathrm{NCHS}$ percentile (5)) or in late recovery $\mathrm{W} / \mathrm{L}=25$ th $\mathrm{NCHS}$ percentile). Written consent was given by each child's parent or guardian. The protocol was approved by the University of Chicago Clinical Investigation Committee and the Ethical Review Committee of the Instituto de Investigacion Nutricionál in Lima, Perú, where the studies were done.

Criteria for admission to the study were height-age of 3 to 18 mo, wt deficit of at least $2.5 \mathrm{Z}$ scores below the National Center for Health Statistics reference median for length (5), no detectable organic disease or edema, serum albumin $>2.5 \mathrm{~g} / \mathrm{dL}$, and wt gain for 3 consecutive d. Children with systemic infections or d:arrhea were excluded until these illnesses were successfully controlled or had resolved. Data were excluded from the analyses if infections, diarrhea [defined as three or more liquid stools/24 $\mathrm{h}$ with or without accompanying blood or mucus (6)], or steatorrhea (defined as fecal fat in excess of $15 \%$ of fat intake) occurred during energy balance studies. A total of 18 children completed two energy balance studies, the first in early recovery and the second in late recovery. Data from five additional children were limited to a single period (four in early recovery only, one in late recovery only) due to infections, diarrhea, or steatorrhea during the other energy balance study. 
Study protocol. The timeline for an energy balance study is shown in Figure 1. The protocol concerning ${ }^{18} \mathrm{O}$ and deuterium was conducted in a manner identical to one already described for deuterium (7). Briefly, on d 0 of each energy balance study, $0.40 \mathrm{~g} \mathrm{H}_{2}^{18} \mathrm{O} / \mathrm{kg}$ (hydrogen normalized water, Mound Laboratories, Miamisburg, $\mathrm{OH}$ ) and $0.11 \mathrm{~g}^{2} \mathrm{H}_{2} \mathrm{O} / \mathrm{kg}$ (Argonne Special Materials, Argonne, IL) were given to measure ${ }^{18} \mathrm{O}$ and deuterium elimination rates from which total daily energy expenditure was calculated $(8)$ and to measure TBW $(9,10)$. Energy balance perdiods averaged $7 \pm 2 \mathrm{~d}$, with a range of 5 to $10 \mathrm{~d}$. The range in periods was necessary to accommodate the range of isotope elimination rates (11). TBW alone was measured on the final $\mathrm{d}$ of the energy balance study after doses of $0.078 \mathrm{~g} \mathrm{H}_{2}{ }^{18} \mathrm{O} / \mathrm{kg}$ and $0.031 \mathrm{~g}^{2} \mathrm{H}_{2} \mathrm{O} / \mathrm{kg}$. Metabolic collections were done on the final 3 rd or 4th d of each energy balance study, as previously described (7), except that all formula intake was measured by feeding bottles which were weighed before and after each feeding. Energy expenditure data were normalized for FFM which was estimated from the dilution spaces of deuterium and ${ }^{18} \mathrm{O}$ as described below.

TBW was measured by ${ }^{2} \mathrm{H}_{2}{ }^{18} \mathrm{O}$ dilution $(9,10)$ on the morning of $\mathrm{d} 0$ and again on the final $\mathrm{d}$ of each energy balance study as previously described (7). To calculate FFM from corrected TBW, we used published hydration coefficients (12) except that the published values were adjusted for a $4 \%$ overestimation of TBW by deuterium dilution rather than for a $1.3 \%$ overestimation $(9$, 10). TBW was calculated from measured dilution spaces corrected by 1.04 and 1.01 for overestimations of TBW by deuterium and ${ }^{18} \mathrm{O}$, respectively $(8)$.

All dietary and water intake was from modified milk-based formulas (Enfalac, Mead-Johnson, Evansville, IN) mixed daily for each child in the metabolic unit and fed in six to eight equalvol feedings/d. Formulas provided 8 or $11 \%$ of energy as protein and 40 to $45 \%$ as CHO. Vitamins and minerals were supplemented (Mead-Johnson).

Metabolic collections were done as previously described during the final 3 or $4 \mathrm{~d}$ of each energy balance study to measure metabolizable energy intake and nitrogen balance (13). Intake was measured from pre- and post-feeding bottle wt. Boys' urinary vol in each 24-h period were measured and aliquots frozen at $-20^{\circ} \mathrm{C}$. Feces were weighed and homogenized, and aliquots were frozen at $-20^{\circ} \mathrm{C}$. For girls, feces and urine were collected together.

Metabolizable energy intake was the arithmetic difference between gross energy intake and the sum of fecal energy and urinary energy. Nitrogen was measured by the micro-Kjeldahl method (14), dietary and fecal calories by bomb calorimetry (15), and fat by the van de Kamer method (16). Urinary calories were calculated as $5.4 \mathrm{kcal} / \mathrm{g}$ urinary nitrogen (17). Nitrogen balance was the difference between intake and the sum of fecal plus urinary nitrogen plus $7.5 \mathrm{mg} \mathrm{N} / \mathrm{kg}$ to estimate unmeasured losses (18). Fat and carbohydrate absorption was estimated as the arithmetic difference between intake $(\mathrm{g} / \mathrm{d})$ and fecal fat or fecal carbohydrate (19) where fecal carbohydrate calories $(4.18 \mathrm{kcal} /$ g) were calculated as the arithmetic difference between total fecal

\begin{tabular}{|c|c|c|c|c|c|c|c|c|c|}
\hline DAY & !) & 1 & $?$ & 3 & $n:$ & $E-4$ & $\underline{E-3}$ & $\underline{E-2}$ & $\underline{E-1}$ \\
\hline \multicolumn{10}{|l|}{ PROCEDLRE } \\
\hline TBW & $x$ & & & & & & & & \\
\hline Energy Expenditure & $x$ & & & & & & & & $\mathrm{x}$ \\
\hline Weighed food intake & & $x$ & $x$ & $x$ & $x$ & $x$ & $x$ & $x$ & $x$ \\
\hline Metabolizable energy & & & & & & $x$ & $\mathrm{x}$ & $x$ & $\mathrm{x}$ \\
\hline Nitrogen balance & & & & & & $x$ & $x$ & $x$ & $x$ \\
\hline
\end{tabular}

Fig. 1. Protocol for early and late recovery energy balance studies. Day E-4...E-1 are the consecutive days before completion of the energy balance study. The ${ }^{2} \mathrm{H}_{2}{ }^{18} \mathrm{O}$ isotopes administered on day 0 measure TBW and energy expenditure; the isotopes administered on $\mathrm{d}$ end were given to measure TBW only. calories and the sum of $\mathrm{kcal}$ from fecal protein $(\mathrm{N} \times 6.25 \times 5.65)$ and fecal fat $(\mathrm{g} \times 9.46)(19)$.

Body wt $( \pm 5 \mathrm{~g})$ was measured daily on a K-tron (K-tron, Scottsdale, AZ) electronic balance, which was calibrated daily.

$\mathrm{CO}_{2}$ production and energy expenditure. $\mathrm{CO}_{2}$ production was measured by the 2-point doubly labeled water method from ${ }^{2} \mathrm{H}$ and ${ }^{18} \mathrm{O}$ enrichment in urine samples, $(8,11,20)$, which were collected between 0600 and $0900 \mathrm{~h}$ the morning after dosing (d 1) and again 4 to 9 d later. An additional urine was collected between $\mathrm{d} 3$ and 6 to test the internal consistency of isotopic analyses. Samples were reanalyzed if $\mathrm{CO}_{2}$ production rates differed by $>10 \%$ between the entire energy balance study and the portions up to the midpoint. No differences $>10 \%$ were found after reanalysis. These midpoint data were not used in calculating rates of $\mathrm{CO}_{2}$ production. Mean daily rates of $\mathrm{CO}_{2}$ production were calculated according to equations 1 and $2(7,20,21)$ :

$$
\begin{gathered}
\mathrm{rCO}_{2}=(\mathrm{N} / 2.078)\left(1.01 \mathrm{k}_{\mathrm{O}}-1.04 \mathrm{k}_{\mathrm{D}}\right) \\
\quad-0.0246 \mathrm{rH}_{2} \mathrm{O}_{\mathrm{f}}, \mathrm{mol} / \mathrm{d} \\
\mathrm{rH}_{2} \mathrm{O}_{\mathrm{f}}=1.36 \mathrm{~N}\left(1.01 \mathrm{k}_{\mathrm{O}}-1.04 \mathrm{k}_{\mathrm{D}}\right), \mathrm{mol} / \mathrm{d}
\end{gathered}
$$

where $\mathrm{rCO}_{2}$ is mean daily $\mathrm{CO}_{2}$ production rate, $\mathrm{k}_{\mathrm{O}}$ and $\mathrm{k}_{\mathrm{D}}$ are isotope elimination rates of oxygen and deuterium, respectively, and $\mathrm{N}$ is mol of body water calculated from mean corrected TBW measurements by both isotopes on the first and last energy balance $d$. As water efflux via transcutaneous and respiratory routes is subject to isotopic fractionation, $\mathrm{rH}_{2} \mathrm{O}_{\mathrm{f}}$ is the rate of water loss via both routes, calculated as a function of $\mathrm{CO}_{2}$ production (20). For our specific study conditions, $\mathrm{rH}_{2} \mathrm{O}_{\mathrm{f}}$ was estimated assuming transcutaneous water efflux is $1.77 \mathrm{rCO}_{2}$ and respiratory water efflux is $1.54 \mathrm{rCO}_{2}(7)$. The standard deviation in $\mathrm{rCO}_{2}$ due to uncertainty in the isotopic enrichment is $5 \%$, estimated for these quantities of isotope administered and average duration of the balance studies (11). Uncertainty in the RQ (see below) to convert $\mathrm{rCO}_{2}$ to energy expenditure increases the uncertainty to $6 \%(11,22)$.

Caloric equivalents of $\mathrm{CO}_{2}$ were estimated from food quotients (22), adjusted for tissue deposition. For this it was assumed that 1) all absorbed carbohydrate was oxidized; 2) protein oxidation equaled $6.25 \times$ urinary nitrogen; 3) the difference between $\mathrm{CO}_{2}$ production and the sum of $\mathrm{CO}_{2}$ from carbohydrate plus protein oxidation was from fat oxidation; 4) $\mathrm{CO}_{2}$ production (liter/g substrate) was $1.427 \mathrm{liter} / \mathrm{g}, 0.766 \mathrm{liter} / \mathrm{g}$, and $0.829 \mathrm{liter} / \mathrm{g}$ for fat, nitrogen, and carbohydrate, respectively (23). Caloric equivalents were $125.4 \pm 3.7$ and $124.6 \pm 4.6 \mathrm{kcal} / \mathrm{mol} \mathrm{CO}$ in the early and late recovery energy balance studies, respectively.

Artifacts in $\mathrm{CO}_{2}$ production rates due to changes in dietary water source and thus in natural isotopic abundance (24) were avoided by dietary equilibration periods before isotope administration of at least $4 \mathrm{~d}$ (range 4 to $20 \mathrm{~d}$ ). In addition, this dietary equilibration followed 7 or more $\mathrm{d}$ of feedings from diets which had different dry ingredients but the same water source used in the study. Adequacy of the equilibration period was demonstrated by the absence of change in baseline enrichments (slope $<0.02 \mathrm{per} \mathrm{mil} / \mathrm{d}$ ) as a function of equilibration period duration.

Energy stored. ES was calculated as the difference between mean daily ME intake and TDEE, measured by the doubly labeled water method. The composition of tissue gained was estimated from nitrogen balance, energy balance, and wt gain, assuming $35.3 \mathrm{kcal} / \mathrm{g}$ nitrogen retained and $9.4 \mathrm{kcal} / \mathrm{g}$ fat.

Development of the model. The mathematical model developed for predicting $\mathrm{ME}$ requirements based on $\mathrm{EE}_{\mathrm{m}+\mathrm{a}}$, energy expended and stored in tissue synthesis, body composition, and rate of wt gain is shown in equation 3 .

$$
\begin{aligned}
\mathrm{ME}=\mathrm{EE}_{\mathrm{m}+\mathrm{a}} \frac{(\mathrm{FFM})}{\mathrm{W}} & +\mathrm{AB}\left(\mathrm{EE}_{\mathrm{f}}+\mathrm{ES}_{\mathrm{f}}\right) \\
& +\mathrm{AC}\left(\mathrm{EE}_{\mathrm{ff}}+\mathrm{ES}_{\mathrm{ff}}\right), \mathrm{kcal} / \mathrm{kg} \text { body wt.d }
\end{aligned}
$$


where:

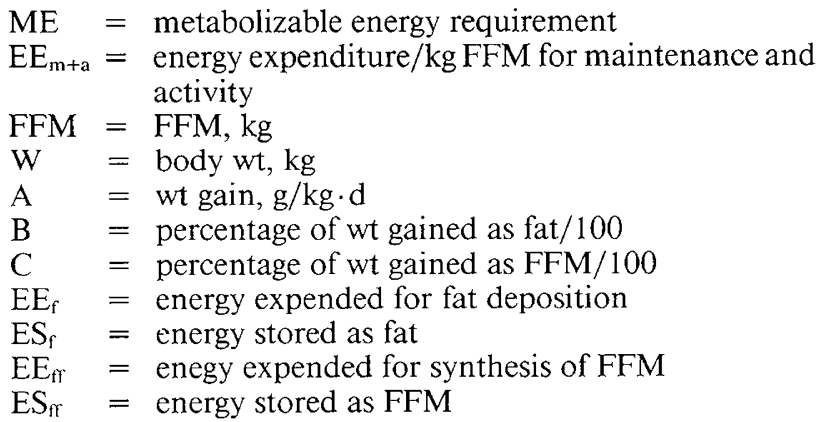

$\mathrm{EE}_{\mathrm{m}+\mathrm{a}}$ was estimated from the difference between total daily energy expenditure and energy expended for tissue synthesis where the latter was calculated from the regression of total daily energy expenditure $(y)$ on weight gain $(x)$. FFM was estimated from TBW as described above. Expenditures for fat and protein deposition were estimated as $1.6 \mathrm{kcal} / \mathrm{g}$ fat $(25,26)$ and as 7.2 $\mathrm{kcal} / \mathrm{g}$ protein respectively $(27,28)$ and used to develop the model. Energy stored as fat was assumed to be $9.46 \mathrm{kcal} / \mathrm{g}$ and $5.65 \mathrm{kcal} / \mathrm{g}$ protein respectively (19). FFM was assumed to be $17 \%$ protein (12). Thus $\mathrm{EE}_{\mathrm{f}}+\mathrm{ES}_{\mathrm{f}}=11.1 \mathrm{kcal} / \mathrm{g}$ and $\mathrm{EE}_{\mathrm{fr}}+\mathrm{ES}_{\mathrm{r}}$ $=2.2 \mathrm{kcal} / \mathrm{g}$.

Isotopic analyses. Isotopic analyses were performed by isotoperatio mass spectrometry as previously described (20). Briefly, the ${ }^{18} \mathrm{O}$ isotope abundances were measured on a Nuclide 3-60 isotope ratio mass spectrometer (MAAS-Nuclide, Belefonte, PA). Urine samples $(1.5 \mathrm{~mL})$ were equilibrated with $1 \mathrm{~mL} \mathrm{STP} \mathrm{of} \mathrm{CO}_{2}$ at $25^{\circ} \mathrm{C}$ for $48 \mathrm{~h}$. The $\mathrm{CO}_{2}$ was isolated under vacuum by cryogenic distillation, and the ${ }^{18} \mathrm{O}$ abundance was measured in ppm (9) relative to a working standard, calibrated against Vienna SMOW. The results were corrected for background, abundance sensitivity, and for ${ }^{13} \mathrm{C}$ and ${ }^{17} \mathrm{O}$ interference (9). Each sample was analyzed in duplicate.

Hydrogen isotope abundances were measured on a Nuclide 3 $60 \mathrm{HD}$ isotope ratio mass spectrometer as previously described, (7). In about one-third of the studies, water from $1 \mu \mathrm{L}$ of urine was isolated by vacuum distillation and then reduced to $\mathrm{H}_{2}$ over uranium turnings (Special Materials, Argonne National Laboratory, Argonne, IL) at $700^{\circ} \mathrm{C}$. In the other two-thirds of the studies, water was reduced over zinc. A total of $2 \mu \mathrm{L}$ of fluid were distilled into a $6-\mathrm{mm}$ outer diameter Vycor (TM) tube containing $80 \mathrm{mg}$ of zinc reagent (Friends of Geology, Bloomington, IN). The $\mathrm{H}_{2}$ was isotopically analyzed against two working standards that had been calibrated against SMOW and Standard Light Arctic Precipitation. The results were corrected for $\mathrm{H}_{3}{ }^{+}$ and other proportional errors by a combination of electrical compensation and double comparison analysis (20) and expressed as the per mil difference from SMOW and corrected for memory on the reduction system. APE of isotopes used for dosing were measured by isotopic ratio mass spectrometry of known dilutions of the stock solutions.

Statistical analysis. Primary data from early and late recovery were compared by paired or group $t$ tests. The mathematical model for predicting ME requirements was fit by linear regression of energy expenditure/kg FFM $(y)$ on wt gain $(x)$. The variance in ME explained by the model was calculated from the regression of predicted $(y)$ on observed $(x)$ ME. The $95 \%$ confidence interval on mean ME was calculated from paired differences between predicted and observed intakes.

\section{RESULTS}

Ages, wts and heights of children in the early and late energy balance studies are listed in Table 1. Rate of wt gain did not differ statistically between study periods. However, statistically significant $(p<0.01)$ differences were seen in body wt and
$\mathrm{W} / \mathrm{L}$ between the two periods, because $\mathrm{W} / \mathrm{L}$ was a criterion of the stage of recovery.

TBW vol, FFM percentage body wt, isotopic elimination rates, and rates of $\mathrm{CO}_{2}$ production in the early and late recovery energy balance studies are shown in Table 2 . FFM was $86 \pm 5.6 \%$ of body wt in the early recovery balance study, and $78 \pm 3.8 \%$ during the late recovery balance study $(p<0.001)$. Comparing only the paired data sets $(n=18)$ did not change the statistical significance of the difference. At the final TBW measurement, when wt was at the 25 th percentile for length (5), TBW averaged $4.96 \pm 0.69 \mathrm{~kg}$ or $60.3 \pm 3.1 \%$ of body wt (range 55 to $66 \%$ ). Body water for reference length-age and 50 th percentile W/L would be approximately $61 \%$ of body wt (recalculated from Ref. 12).

ME intake increased from $877 \pm 170$ to $1020 \pm 194 \mathrm{kcal} / \mathrm{d}$ between the early and late periods equivalent to $90.5 \pm 2.2 \%$ and $91.4 \pm 1.9 \%$ of daily gross intake $(p>0.10)$ in the respective periods. Table 3 lists energy intake $/ \mathrm{kg}$ body wt. There were no statistically significant differences ( $\mathrm{kcal} / \mathrm{kg}$ body wt) between group means for gross caloric intake, caloric losses in excreta, or ME when these values were compared by stage of recovery (Fig. 2).

No statistically significant differences were found for mean TDEE $(\mathrm{kcal} / \mathrm{kg}$ body weight $\cdot \mathrm{d})$ or for $\mathrm{ES}(\mathrm{kcal} / \mathrm{kg} \cdot \mathrm{d})$ when these were compared by stage of recovery (Table 4). However, paired comparisons from the 18 children who completed both balance

Table 1. Selected characteristics of children in early and late recovery energy balance studies*

\begin{tabular}{lcc}
\hline & $\begin{array}{c}\text { Early recovery } \\
(n=22)\end{array}$ & $\begin{array}{c}\text { Late recovery } \\
(n=19)\end{array}$ \\
\hline Age $(\mathrm{mo})$ & $16.0 \pm 6.5$ & $16.3 \pm 5.3$ \\
Wt $(\mathrm{kg})$ & $6.99 \pm 1.30$ & $8.24 \pm 1.20$ \\
Length $(\mathrm{cm})$ & $70.9 \pm 5.2$ & $71.8 \pm 4.9$ \\
Length-age $(\mathrm{mo})$ & $8.5 \pm 3.4$ & $9.2 \pm 3.4$ \\
W/L $\dagger$ & $-2.2 \pm 0.4$ & $-0.9 \pm 0.3$ \\
W/A $\dagger$ & $-3.4 \pm 0.7$ & $-2.3 \pm 0.5$ \\
L/A $\dagger$ & $-2.9 \pm 1.2$ & $-2.7 \pm 1.0$ \\
Wt gain, g/kg.d & $7.3 \pm 3.8$ & $7.6 \pm 3.6$ \\
\hline
\end{tabular}

$*$ All values are mean $\pm \mathrm{SD}$.

$\dagger \mathrm{Z}$ scores, mean wt-for-length (W/L), wt-for-age (W/A), and lengthfor-age (L/A) (5).

Table 2. Isotope dilution and elimination in early and late recovery energy balance studies*

\begin{tabular}{lcc}
\hline & $\begin{array}{c}\text { Early recovery } \\
(n=22)\end{array}$ & $\begin{array}{c}\text { Late recovery } \\
(n=19)\end{array}$ \\
\hline Body wt, kg & $6.99 \pm 1.30$ & $8.24 \pm 1.20$ \\
Total body water, $\mathrm{kg}$ & $4.58 \pm 0.72$ & $4.96 \pm 0.69$ \\
Fat-free mass, \% body wt & $86 \pm 5.6$ & $78 \pm 3.8$ \\
$\mathrm{k}_{\mathrm{H}}, \mathrm{d}^{-1}$ & $0.2736 \pm 0.0343$ & $0.2833 \pm 0.0352$ \\
$\mathrm{k}_{\mathrm{O}}, \mathrm{d}^{-1}$ & $0.3255 \pm 0.0367$ & $0.3368 \pm 0.0323$ \\
$\mathrm{rCO}, \mathrm{mol} \pm \mathrm{d}^{-1}$ & $4.95 \pm 0.79$ & $5.52 \pm 0.78$ \\
$\mathrm{kcal} \cdot \mathrm{mol} \mathrm{CO}_{2}^{-1}$ & $125.4 \pm 3.7$ & $124.6 \pm 4.6$ \\
\hline
\end{tabular}

$*$ All values are mean $\pm \mathrm{SD}$.

Table 3. Energy intake, expenditure, and storage $\left(\mathrm{kcal} \cdot \mathrm{kg}^{-1}\right.$. $d^{-1}$ ) in early and late recovery energy balance studies*

\begin{tabular}{lccc}
\hline & $\begin{array}{c}\text { Early recovery } \\
(n=22)\end{array}$ & $\begin{array}{c}\text { Late recovery } \\
(n=19)\end{array}$ & $p$ \\
\hline Gross energy intake & $140.4 \pm 22.0$ & $136.1 \pm 26.3$ & NS \\
Fecal energy & $11.8 \pm 3.4$ & $10.4 \pm 3.9$ & NS \\
Urinary energy & $1.5 \pm 0.7$ & $1.4 \pm 0.7$ & NS \\
Metabolizable energy & $127.1 \pm 20.5$ & $124.3 \pm 23.2$ & NS \\
\hline
\end{tabular}

$*$ All values are mean $\pm \mathrm{SD}$. 


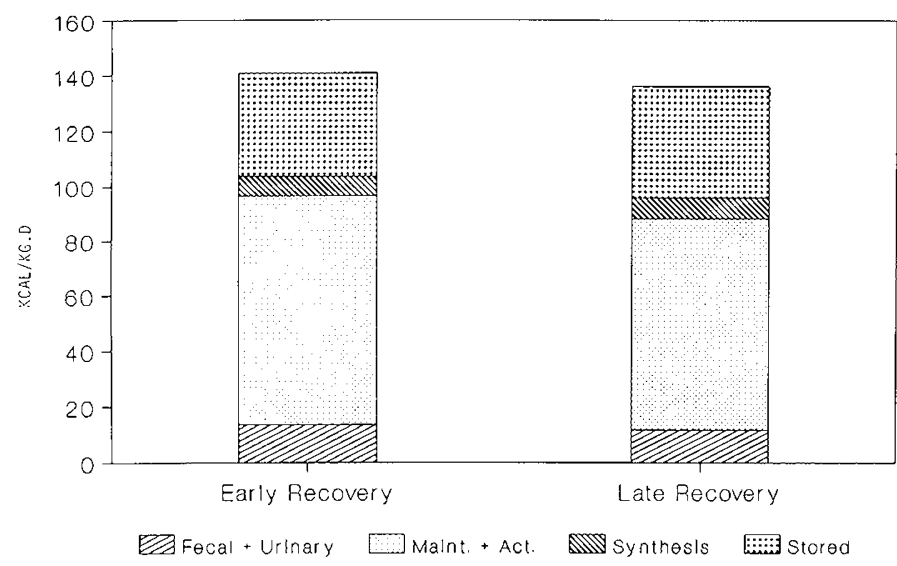

Fig. 2. Energy partitioned to fecal and urinary output, maintenance and activity, tissue synthesis, and in early and late recovery from PEM.

Table 4. Energy partitioning in early and late recovery energy balance studies

\begin{tabular}{|c|c|c|c|}
\hline & $\begin{array}{l}\text { Early recovery } \\
\quad(n=22)\end{array}$ & $\begin{array}{l}\text { Late recovery } \\
\qquad(n=19)\end{array}$ & $p$ \\
\hline $\begin{array}{l}\text { Energy expended* }(\mathrm{kcal} / \mathrm{kg} \\
\qquad \mathrm{FFM} \pm \mathrm{SD})\end{array}$ & $105 \pm 12$ & $107 \pm 13$ & NS \\
\hline $\begin{array}{l}\text { Energy expended* }(\mathrm{kcal} / \mathrm{kg} \\
\text { body wt } \pm \mathrm{SD})\end{array}$ & $90 \pm 12$ & $84 \pm 10$ & NS \\
\hline $\begin{array}{l}\text { Maintenance }+ \text { activity* } \\
(\text { kcal/kg FFM } \pm \mathrm{SD})\end{array}$ & $97 \pm 12$ & $98 \pm 13$ & NS \\
\hline $\begin{array}{l}\text { Maintenance }+ \text { activity* } \\
\quad(\mathrm{kcal} / \mathrm{kg} \pm \mathrm{SD})\end{array}$ & $83 \pm 5.4$ & $76 \pm 3.7$ & $<.01$ \\
\hline $\begin{array}{l}\text { Tissue formation* }(\mathrm{kcal} / \mathrm{g} \\
\text { gain } \pm \mathrm{SE})\end{array}$ & $1 \pm 0.6$ & $1 \pm 0.6$ & NS \\
\hline $\begin{array}{l}\text { Energy stored } *(\mathrm{kcal} / \mathrm{g} \text { gain } \\
\quad \pm \mathrm{SD})\end{array}$ & $5.5 \pm 2.4$ & $5.6 \pm 2.5$ & NS \\
\hline
\end{tabular}

* See "Methods," development of the equation, which defines these terms.

studies showed higher levels of TDEE $(\mathrm{kcal} / \mathrm{kg} \cdot \mathrm{d})$ in the early than in the late energy balance study (mean difference $=6.8 \pm$ $2.4 \mathrm{kcal} / \mathrm{kg} \cdot \mathrm{d} ; p<0.001)$.

$\mathrm{EE}_{\mathrm{m}+\mathrm{a}}(\mathrm{kcal} / \mathrm{kg} \cdot \mathrm{d})$ was statistically greater in early than in late recovery $(p<0.01)$ (Table 4$)$. However, when $\mathrm{EE}_{\mathrm{m}+\mathrm{a}}$ was normalized for FFM, there was no difference between early (97 \pm $12 \mathrm{kcal} / \mathrm{kg}$ FFM $\cdot \mathrm{d})$ and late $(98 \pm 13 \mathrm{kcal} / \mathrm{kg}$ FFM $\cdot \mathrm{d})$ recovery for either group means $(p>0.50)$ or for the 18 paired comparisons (mean difference early recovery - late recovery $=-0.7 \pm$ $1.9 \mathrm{kcal} / \mathrm{kg} \mathrm{FFN} \cdot \mathrm{d} ; p>0.10$ ). The relationship between TDEE in early and late recovery is plotted against FFM in Figure 3.

Mean rates of wt gain were $7.3 \pm 3.8(2$ to $15 \mathrm{~g} / \mathrm{kg} \cdot \mathrm{d})$ and 7.6 $\pm 3.6(2$ to 12.5$) \mathrm{g} / \mathrm{kg} \cdot \mathrm{d}$, respectively, in early and late recovery energy balance studies (Table 1). ES was $37 \pm 8 \mathrm{kcal} / \mathrm{kg}$ body wt in early recovery and $40 \pm 24 \mathrm{kcal} / \mathrm{kg}$ in late recovery, equivalent to $5.5 \pm 2.4$ and $5.6 \pm 2.5 \mathrm{kcal} / \mathrm{g}$ gain $(p>0.5)$ in the respective periods and corresponds to an estimated $50 \%$ of wt gained as fat (Table 4). At these caloric intakes, approximately $67 \pm 9.2 \%$ of $\mathrm{ME}$ intake was partitioned to maintenance and activity and 28 $\pm 10.6 \%$ to storage in early recovery compared to $64 \pm 10.9 \%$ and $30 \pm 13.7 \%$ in late recovery.

$M o d e l$ for predicting $M E$ requirements during recovery. Using the mathematical model (equation 3) for ME requirements during recovery and catch-up growth in malnourished children and substituting the value for $\mathrm{EE}_{\mathrm{m}+\mathrm{a}}$ from Table 4 yields:

$$
\begin{aligned}
\mathrm{ME}=\left[98 \times \frac{\mathrm{FFM}}{\mathrm{W}}+\mathrm{A}\right. & (11.1 \mathrm{~B} \\
& +2.2 \mathrm{C})], \mathrm{kcal} / \mathrm{kg}, \text { body } \mathrm{wt} \cdot \mathrm{d}^{-1}
\end{aligned}
$$

This model accounts for $80 \%$ of the variance in actual $\mathrm{ME}$ intake in these children. The $y$ intercept of the regression of

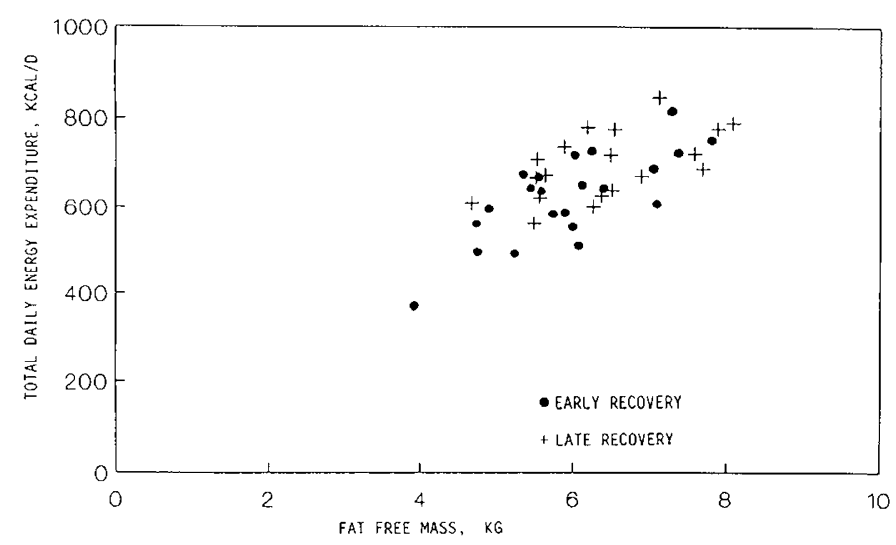

Fig. 3. Total daily energy expenditure $v s$. FFM in early and late recovery energy balance studies $y=(79 \pm 12) x+(162 \pm 72), \mathrm{kcal} / \mathrm{d}$.

predicted ME required $(y)$ versus observed $\mathrm{ME}$ intake was $-3 \pm$ $11 \mathrm{SE} \mathrm{kcal} / \mathrm{kg} \cdot \mathrm{d}$, and the slope was $1.1 \pm 0.09 \mathrm{kcal} / \mathrm{kg} \cdot \mathrm{d}$. The $95 \%$ confidence interval on mean predicted values was $\pm 4 \mathrm{kcal} /$ $\mathrm{kg} \cdot \mathrm{d}$.

We also compared predicted intake with measured caloric intake in a separate group of children. The prediction was based on equation 4, measured rates of wt gain, estimated body composition, and composition of wt gain in 88 children during recovery from malnutrition (Graham $\mathrm{G}$, Gastanaday A, unpublished data, Instituto de Investigación Nutricionál). Data from six groups, whose height-ages ( 3 to $20 \mathrm{mo}$ ), stages of recovery (5th to 25 th percentile $\mathrm{W} / \mathrm{L}$ ), and clinical management were comparable to those of the children in the present study were available. The fat-free portion of wt gain was estimated from an assumed hydration of $77 \%$ (12). Initial body water percentage of wt was estimated from initial wt and the regression equation of body water percentage of wt on W/L in the present study. Final body water was assumed to be $61 \%$ body wt, as final body wt was equivalent to the median for length. Rates of wt gain were 3 to $5 \mathrm{~g} / \mathrm{kg} \cdot \mathrm{d}$. Gross intake was determined by vol intake and diet composition and ranged from 103 to $127 \mathrm{kcal} / \mathrm{kg} \cdot \mathrm{d}$, metabolizable intake was assumed to be $90 \%$ of gross intake. Activity was assumed to be comparable with the present study as all children participated in the same play/stimulation program. Under these conditions, the metabolizable energy requirement predicted by equation 4 was $95 \mathrm{kcal} / \mathrm{kg} \cdot \mathrm{d}$ versus actual measured ME intakes of $100 \pm 7 \mathrm{kcal} / \mathrm{kg} \cdot \mathrm{d}$.

\section{DISCUSSION}

Using the doubly labeled water method, we were able to complete energy balance studies under conditions where other methods are difficult to apply and to develop a model for predicting metabolizable energy requirements of malnourished infants during catch-up growth. Because the new model for predicting metabolizable energy requirements is based on energy expenditure and body composition measured by the doubly labeled water method, which has never been used in a study of catch-up growth in children, several of the assumptions of the method merit discussion.

We assumed that the 5 to $6 \%$ increase in the dilution space due to growth was linear over the energy balance period. Thus the TBW vol used to calculate $\mathrm{CO}_{2}$ was the mean of these initial and final measures. The greatest error in the calculation of $\mathrm{CO}_{2}$ production that could arise from this assumption would be in a hypothetical case in which the TBW vol was unchanged from $\mathrm{d}$ 0 until near the end of the study, but then suddenly increased by the same percentage, but over only $1 \mathrm{~d}$. This is highly unlikely; however, even if this occurred, the estimate of energy expenditure would have been wrong by only $2 \%$ (11).

It was also assumed that water was the only route by which deuterium exits the body water pool, and that water and $\mathrm{CO}_{2}$ 
were the only routes of oxygen elimination. During rapid wt gain, de novo fat synthesis would sequester hydrogen and deuterium and could cause underestimates of energy expenditure. We believe that did not occur in our study. In a validation of the doubly labeled water method against intake-balance in total parenteral nutrition patients (8) where de novo synthesis was also a concern, total daily energy expenditure by the doubly labeled water method was $3 \%$ greater than by the intake-balance method. If de novo synthesis had been responsible for the formation of the estimated $30 \%$ of fat deposited during the $135 \mathrm{~g} / \mathrm{d}$ wt gain, then energy expenditure would have been underestimated by $5 \%$. Furthermore, the recent validations of the method in rapidly growing infants $(2,3)$ demonstrated that energy expenditure from doubly labeled water does not differ from that measured by respiratory gas exchange. These results indicate that deuterium sequestration does not occur to an extent that would cause estimates of energy expenditure to be off significantly in rapidly growing humans.

The third assumption is that water within the body, water eliminated from the body, and water in fluid samples used for isotopic analysis all have equal isotopic enrichment. However, heavy and light isotopes do not partition equally between body water and expired gases. Uncorrected, this would result in an overestimate of $\mathrm{CO}_{2}$ production in infants and young children. Corrections for isotopic fractionation effects have been estimated (20) based on the observation that urinary and sweat water are isotopically equivalent to body water but transcutaneous and respiratory water and $\mathrm{CO}_{2}$ are isotopically fractionated $(21,29)$. Infants and young children differ, however, in that they have higher water turnover rates, higher metabolic rates $/ \mathrm{kg}$ body wt, and more body surface area $/ \mathrm{kg}$ body wt than adults. Thus we modified the estimation of water lost via breath and transcutaneous water vapor (7). This modification, however, was slight and only leads to a $2 \%$ difference in calculated $\mathrm{CO}_{2}$ production.

The basic assumptions of the doubly labeled water method do not appear to be violated in malnourished infants at the stages of recovery studied and thus, large systematic errors are unlikely.

Previous estimates of energy requirements for maintenance and activity during catch-up growth, calculated from the intercept of the regression of energy intake on wt gain ranged from 80 to $114 \mathrm{kcal} / \mathrm{kg} \cdot \mathrm{d}(30-32)$. The one study in which energy expenditure was measured (33) concluded $82 \mathrm{kcal} / \mathrm{kg}$. d were required for maintenance and activity. However, these results were never confirmed and neither that study (33) nor the studies based on energy intake considered body composition. The new model for predicting energy requirements (equation 4) is based on energy expenditure normalized for the metabolically active FFM, and thus should improve predictions of energy requirements.

Variation in energy expenditure/ $\mathrm{kg}$ body wt differed between early and late recovery because energy expended to meet maintenance needs varies as a function of body composition. As indicated in our study, children at earlier stages of recovery have relatively greater depletions of fat stores, higher proportions of FFM, and hence elevated expenditures/kg body wt.

Variation in energy expenditure/ $\mathrm{kg}$ body wt was removed and the findings made more widely applicable by normalizing energy expenditure for FFM. Energy expenditure for maintenance and activity was $97 \pm 12$ and $98 \pm 13 \mathrm{kcal} / \mathrm{kg}$ FFM, and not statistically different between early and late balance studies. Although the finding of constant levels of energy expenditure/ $\mathrm{kg}$ FFM may seem surprising as adult studies have shown decreased energy expenditure/kg FFM during semistarvation (34), it should be pointed out that children in our study were already gaining wt in the early recovery study. Furthermore, although we have seen no net difference in expenditure $/ \mathrm{kg}$ FFM between early and late recovery, there may have been physiologic differences with opposite effects on expenditure/kg FFM that were not detected by our study design. In particular, it is possible that the more metabolically active organs occupied a relatively larger proportion of FFM in early than in late recovery, leading to a higher level of expenditure in the early period. Increased activity in late recovery could have masked this effect.

Normalization of energy expenditure by FFM was done from TBW using reference hydration constants. Although there is the possibility that the composition of FFM is altered during malnutrition, evidence suggested reference hydration coefficients were appropriate in the present study. The primary evidence is that TBW was $61 \%$ of the body wt in children who had repleted their wt deficits, and thus comparable with reference composition (12). Reference hydration constants are thus probably valid in late recovery. In early recovery, TBW occupied a much larger proportion of body wt, but this appears to have been due to decreased fat mass rather than to overhydration of the FFM. The evidence for this is that ratios of water accretion to protein accretion are $3 \mathrm{~g} \pm 1.6 \mathrm{~g}$ water $/ \mathrm{g}$ protein in early recovery and 3 $\mathrm{g} \pm 1.1 \mathrm{~g}$ water $/ \mathrm{g}$ protein in late recovery and indicate reference hydration of the tissue gained (12).

Energy expenditure for activity may also influence energy requirements. Though we do not have precise measures of activity, we estimate that during $24 \mathrm{~h}$ in either early or late recovery, $10 \mathrm{~h}$ were spent sleeping, $6 \mathrm{~h}$ awake in bed, $3 \mathrm{~h}$ playing, $3 \mathrm{~h}$ eating, and $2 \mathrm{~h}$ in bathing and changing clothes. Based on an estimated resting metabolic rate of $60 \mathrm{kcal} / \mathrm{kg}$ (1) we calculate that $20 \%$ of the ME intake was expended for activity. Thus, large differences in levels or duration of activity would be required to alter significantly the estimated total energy requirement.

As indicated in the development of the model, the energy cost of tissue synthesis in infants will also vary depending on the composition of tissue deposited. Using data from a review of low birth wt infant studies (25), expenditure for formation of fat from dietary triglycerides is $1.8 \mathrm{kcal} / \mathrm{g}$, and that for protein is 7.6 $\mathrm{kcal} / \mathrm{g}$. Similarly, evidence from studies of growing pigs and rats $(26-28,35)$ suggests expenditure for fat deposition from dietary triglycerides and for protein synthesis is 1.4 and $7.2 \mathrm{kcal} / \mathrm{g}$, respectively. Our observed value of $1 \mathrm{kcal} / \mathrm{g}$ is consistent with these values. In the present study in which 40 to $50 \%$ of the wt gained was fat, the calculated energy cost for forming this tissue, assuming $17 \%$ of FFM is protein (12), would be $1.3 \mathrm{kcal} / \mathrm{g}$, which is quite similar to the observed value. Very similar values of 1.3 (35) and 1.1 (33) $\mathrm{kcal} / \mathrm{g}$ have also been reported for very low birth wt infants, gaining $15 \mathrm{~g} / \mathrm{g}$ wt gain and in malnourished children, respectively.

Energy requirements (kcal/kg body wt) for medically uncomplicated catch-up growth in PEM children depend on the level of depletion of fat stores and on the rate and composition of wt gain during nutritional repletion. Using the new model in equation 4 , we have developed a mathematical model which can easily be used in clinic or field settings to estimate ME requirements (Table 5).

We also used the model to predict energy requirements for a hypothetical reference infant to compare the FAO/WHO (1) estimates which had been based on energy intake. We assumed reference body wt and composition, i.e. that $76 \%$ to $77 \%$ of body wt at 9 mo of age is FFM, that wt gain is $1.5 \mathrm{~g} / \mathrm{kg} \cdot \mathrm{d}$, and contains

Table 5. Metabolizable energy requirements for catch-up growth in children recovering from PEM predicted by equation 4 according to body composition, rate and composition of weight gain

\begin{tabular}{cccc}
\hline $\begin{array}{r}\text { Wt gain } \\
(\mathrm{g} / \mathrm{kg} \cdot \mathrm{d})\end{array}$ & $\begin{array}{c}\text { Wt gain } \\
(\% \text { FFM })\end{array}$ & $\begin{array}{c}\text { Body Composition } \\
(\mathrm{Wt} \% \text { FFM })\end{array}$ & $\begin{array}{c}\text { Metabolizable Energy } \\
(\mathrm{kcal} / \mathrm{kg} \cdot \mathrm{d})\end{array}$ \\
\hline 0 & 0 & 90 & 88 \\
5 & 30 & 90 & 130 \\
15 & 0 & 90 & 255 \\
15 & 50 & 90 & 188 \\
0 & 0 & 75 & 74 \\
5 & 30 & 75 & 116 \\
15 & 0 & 75 & 240 \\
15 & 50 & 75 & 173 \\
\hline
\end{tabular}


$14 \%$ fat (12). The metabolizable energy requirement predicted from equation 4 is $80 \mathrm{kcal} / \mathrm{kg} \cdot \mathrm{d}$. The FAO/WHO (1) dietary recommendations are for $91 \mathrm{kcal} / \mathrm{kg} \cdot \mathrm{d}$ for healthy children in this age group. Because our data include children near the end of recovery, it is likely that our values can be extrapolated to healthy children. As such, our method based on energy expenditure and body composition suggest that the FAO/WHO estimation (1) of metabolizable energy requirements should be reevaluated.

Our tests of the model have not been rigorous. However, preliminary tests of the model indicated it accurately predicted energy requirements of infants and young children recovering from PEM and of healthy recovered children.

Acknowledgments. The authors thank the staff at the Instituto de Investigacion Nutricional, Drs. Arturo Gastañaduy and George Graham for useful discussions and auxiliary patient data to test equation 4, C. Leitch for technical assistance, and Kim Thoma for manuscript preparation.

\section{REFERENCES}

1. FAO/WHO/UNU Food and Agricultural Organization. 1985. Energy and protein requirements: report of a joint FAO/WHO Ad Hoc Expert Committee. FAO/WHO/UNU, Geneva. (Tech Report Ser No 724)

2. Roberts SB, Coward WA, Schlingenseipen K-H, Nohria V Lucas A 1986 Comparison of the doubly labeled water $\left({ }^{2} \mathrm{H}_{2}{ }^{18} \mathrm{O}\right)$ method with indirect calorimetry and a nutrient-balance study for simultaneous determination of energy expenditure, water intake, and metabolizable energy intake in preterm infants. Am J Clin Nutr 44:315-22

3. Jones PJH, Winthrop AL, Schoeller DA, Swyer PR, Smith J, Filler RM, Heim T 1987 Validation of doubly labeled water for assessing energy expenditure in infants. Pediatr Res 21:242-246

4. Rose HE, Mayer J 1968 Activity, calorie intake, fat storage, and the energy balance of infants. Pediatrics 41:18-29

5. National Center for Health Statistics: Growth Curves for Children 0 to 18 years. 1977 United States, Vital and Health Statistics. Series II. No 165. Government Printing Office, Washington, DC

6. Brown $\mathrm{KH}$, Gastañaduy AS,Saavedra JM, Lembcke J, Rivas D, Robertson AD, Yolken R, Sack RB 1988 Effect of continued oral feeding on clinical and nutritional outcomes of acute diarrhea in children. J Pediatr 112:191200

7. Fjeld $\mathrm{CR}$, Brown $\mathrm{KH}$, Schoeller DA 1988 Validation of the deuterium oxide method for measuring average daily milk intake in infants. Am J Clin Nutr 48:671-679

8. Schoeller DA 1988 Measurement of energy expenditure in free-living humans using doubly labeled water. J Nutr, 1 18:1278-1289

9. Schoeller DA, van Santen E, Peterson DW, Deitz W, Jaspan J, Klein PD 1980 Total body water measurements in humans with ${ }^{18} \mathrm{O}$ and ${ }^{2} \mathrm{H}$ labeled water. Am J Clin Nutr 33:2686-2693

10. Culebras JM and Moore FD 1977 Total body water and the exchangeable hydrogen. I. Theoretical calculation of nonaqueous exchangeable hydrogen in man. Am J Physiol 232:R54-59

11. Schoeller DA 1983 Energy expenditure from doubly labeled water; some fundamental considerations. Am J Clin Nutr 38:999-1005

12. Fomon SJ, Haschke F, Ziegler EE, Nelson SE 1982 Body composition of reference children from birth to age 10 years. Am J Clin Nutr 35:1169-1175

13. Graham GG, Cordano A, Morales E, Acevedo G, Placko RP 1969 Dietary protein quality in infants and children. II. Metabolic studies with cottonseed flour. Am J Clin Nutr 22:577-587

14. Horwitz W (ed) 1975 Official Methods of Analysis. 12th ed Association of Official Analytical Chemists, Washington, DC

15. Raymond WF, Canaway RJ, Harris CE 1957 An automatic adiabatic bomb calorimeter. J Sci Instrum 34:501-503

16. Van de Kamer JH, Ten Bokkel Huimink H, Weyers HA 1949 Rapid method for determination of fat in feces. J Biol Chem 177:347-355

17. Kleiber M 1975 The Fire of Life. An Introduction to Animal Energetics. RE Krieger, Huntington, pp 267-268

18. Cooke RE, Pratt EL, Darrow DC 1950 The metabolic response of infants to heat stress. Yale J Biol Med 22:228-249

19. Lusk G 1924 Animal calorimetry: analysis of oxidation of mixtures of carbohydrates and fat. J Biol Chem 59:41-42

20. Schoeller DA, Ravussin E, Schultz Y, Acheson KJ, Baertschi P, Jequier E 1986 Energy expenditure by doubly labeled water: validation in humans and proposed calculation. Am J Physiol 250:R823-830

21. Schoeller DA, Leitch CA, Brown C 1986 Doubly labeled water method: in vivo oxygen and hydration isotope fractionation. Am J Physiol 251:R1137-1143

22. Black AE, Prentice AM, Coward WA 1986 Use of food quotients to predict respiratory quotients for the doubly-labelled water method of measuring energy expenditure. Hum Nutr: Clin Nutr 40C:381-391

23. Lusk G 1976 The Elements of the Science of Nutrition, 4th ed. Academic Press, New York

24. Jones PJH, Winthrop AL, Schoeller DA, Filler RM, Swyer PR, Smith J, Hern T 1988 Evaluation of doubly labeled water for measuring energy expenditure during changing nutrition. Am J Clin Nutr 47:799-804

25. Roberts SB, Young VR 1988 The energy costs of fat and protein deposition in the human infant. Am J Clin Nutr 48:951-955

26. Joint ARC/MRC Committee 1974 Food and Nutrition Research report of ARC/MRC Committee, HM Stationery Office, London

27. Millward DJ, Garlick PJ 1976 Energy cost of growth. Proc Nutr Soc 35:339349

28. Pullar JD and Webster AJF 1974 Heat loss and energy retention during growth in genetically obese and lean rats. Br J Nutr 31:377-392

29. Wong WW, Cochran WJ, Klish WJ, Smith EOB, Lee LS, Klein PD 1988 In vivo isotope fractionation and the measurement of deuterium and oxygen18 dilution spaces from plasma, urine, saliva, respiratory water vapor, and carbon dioxide. Am $\mathrm{J}$ Clin Nutr 47:1-6

30. Ashworth A, Millward DJ 1986 Catch-up growth in children. Nutr Rev 44:157163

31. Jackson AA, Chir B, Picou D, Reeds, PJ 1977 The energy cost of repleting tissue deficits during recovery from protein-energy malnutrition. Am J Clin Nutr 30:1514-1517

32. Whitehead RG 1977 Protein and energy requirements of young children living in the developing countries to allow for catch-up growth after infections. Am $\mathrm{J}$ Clin Nutr 30:1545-1547

33. Spady DW, Payne PR, Picou D, Waterlow JC 1976 Energy balance during recovery from malnutrition. Am J Clin Nutr 29:1073-1078

34. Keys A, Brozek J, Henschel A, Mickelsen O, Taylor HL 1950 Basal metabolism. In: The Biology of Human Starvation, vol 1. University of Minnesota Press, Minneapolis, pp 303-339

35. Pullar JD, Webster AJF 1977 The energy cost of fat and protein deposition in the rat. Br J Nutr 37:355-363

36. Catzeflis C, Schutz Y, Micheli J-L, Welsch C, Arnaud MJ, Jequier E 1985 Whole body protein synthesis and energy expenditure in very low birth weight infants. Pediatr Res 19:679-687 